\title{
Marta Kurkowska-Budzan
}

[Kraków]

(D) https://orcid.org/0000-0002-8597-9320

\section{Emilia Soroko}

[Poznań]

(D) https://orcid.org/oooo-0003-3527-1698

\section{Marcin Stasiak}

[Kraków]

(D) https://orcid.org/0000-0001-7499-7083

\section{Wywiad ustrukturyzowany w badaniach historycznych. Propozycja procedury badawczej}

\section{[Structured Interview in Historical Research.} A Proposed Research Procedure]

DOI: $10.26774 / \mathrm{wrhm} .269$

\begin{abstract}
The text presents the procedures and techniques involved in a research method aimed at "evoking a historical source", which is understood as a researcher's prepared and academically rigorously implemented participation in the creation by a witness to history of such recollective material that might be a carrier of information and that might be subject to rudimentary historical analysis. The text presents defined assumptions and subsequent stages of the proposed research procedure.
\end{abstract}

\section{Keywords}

research method, autobiographical memory as a historical source, structured interview, procedures and techniques

\section{Słowa kluczowe}

metoda badawcza, pamięć autobiograficzna jako źródło historyczne, wywiad ustrukturyzowany, procedury i techniki 
Steinar Kvale opisując dwa równoprawne epistemologiczne stanowiska funkcjonujące współcześnie w naukach społecznych i humanistycznych, w których znajduje zastosowanie technika wywiadu, posłużył się metaforami „badacza-górnika” i „badacza-podróżnika”. „Górnik” gromadzi wiedzę, wydobywając ją z materiału empirycznego w postaci obiektywnych faktów lub autentycznych, choć subiektywnych znaczeń. „Podróżnik” bierze świadomy udział w procesie konstruowania wiedzy, który toczy się głównie w polu języka, zatem przedmiotem jego naukowego zainteresowania stają się opowieści i dyskursy same w sobie ${ }^{1}$.

Historia jest gościnną krainą, w której zarówno „górnik”, jak i „podróżnik” dobrze się odnajdują. Z myślą o badaczach identyfikujących się z tym drugim stanowiskiem epistemologicznym podjęliśmy próbę wypracowania procedury wywiadu, który zaliczyć należy do grupy wywiadów ustrukturyzowanych. Projektując metodę, mieliśmy na uwadze określoną koncepcję uzyskiwanej w trakcie badania wiedzy, nie twierdzimy jednak, że to uniwersalna czy najlepsza metoda wywiadu dla każdego historyka. Proponujemy procedury badawcze, których celem jest „wywołanie źródła historycznego”. Rozumiemy przez to przygotowany i zrealizowany w rygorze naukowym udział badacza w stworzeniu przez respondenta (świadka historii) takiego materiału wspomnieniowego, który będzie nośnikiem informacji i będzie mógł być poddany rudymentarnej analizie historycznej, tzn. skonfrontowaniu lub/i weryfikacji z informacjami z innych źródeł.

Przedstawione w tekście procedury² ${ }^{2}$ choć opisują głównie przygotowanie wywiadu, nie dotyczą tylko jego techniki. Są metodą w tym znaczeniu, że zakładają pewne cele epistemologiczne i wymagany do ich osiągnięcia, zdefiniowany reżim metodologiczny oraz typ analizy przewidywany w projekcie badawczym. Nie omawiamy tej ostatniej, ponieważ jest to kwestia wymagająca odrębnego, obszernego artykułu ${ }^{3}$. Nie obstajemy też przy twierdzeniu, że przy tej metodzie możliwa czy wskazana jest tylko podstawowa analiza historyczna.

1 S. Kvale, Prowadzenie wywiadów, Warszawa 2010, s. 53-54.

2 Artykuł prezentuje rezultaty projektu badawczego finansowanego ze środków Narodowego Centrum Nauki, nr umowy: 2015/19/B/H 33/01761, realizowanego w Instytucie Historii Uniwersytetu Jagiellońskiego w Krakowie.

3 Procedury były kilka razy modyfikowane po kolejnych partiach testów przez członków zespołu badawczego i studentów. Nieocenioną pomoc na etapie testów okazali nam wolontariusze - studenci z Instytutu Historii Uniwersytetu Jagiellońskiego, za co bardzo im dziękujemy. Za szczególne zaangażowanie dziękujemy magistrantom: pani Karolinie Domańskiej i panu Markowi Woźniakowi oraz doktorantce, pani Soni Knapczyk. 
W pierwszej części tekstu przybliżamy ustalenia naukowe z zakresu psychologii, na których budowaliśmy metodę. W zasadniczej części definiujemy podstawowe założenia i procedury oraz podajemy $\mathrm{w}$ formie tabeli mechanikę przekuwania ich w kwestionariusz i komunikację podczas wywiadu. Jako załącznik do artykułu przedstawiamy instrukcję komunikacji podczas kontraktowania badania, która, przy oczywistych adaptacjach do danego projektu, może być narzędziem uniwersalnym.

Zaprezentowaną metodę uważamy za otwartą na uzupełnienia i modyfikacje. Liczymy szczególnie na uwagi ze strony historyków-praktyków, którzy zechcą ją przetestować i przedyskutować na forum „Wrocławskiego Rocznika Historii Mówionej" swoje doświadczenia ${ }^{4}$.

\section{Założenia ogólne}

Wywiad badawczy w swojej ogólnej formie to „rozmowa, której struktura i cel są określone przez jedną ze stron - osobę przeprowadzającą wywiad. Jest to profesjonalna interakcja, która [...] polega na starannym zadawaniu pytań oraz uważnym wysłuchiwaniu odpowiedzi w celu zdobycia szczegółowo sprawdzonej wiedzy"5.

Proponowaną tu metodę wywiadu definiujemy zatem jako procedury, według których przebiega rozmowa na temat zdarzeń z przeszłości. Procedury zostały opracowane na podstawie aktualnego dorobku światowej psychologii na temat funkcjonowania pamięci autobiograficznej i epizodycznej oraz wiedzy o zasadach prowadzenia wywiadów pogłębionych, częściowo ustrukturyzowanych, które zakładają dynamikę kontaktu interpersonalnego oraz podstawowe umiejętności komunikacyjne. Temat wywiadu, którym może być określone zdarzenie (zdarzenia), zakres czasu lub grupa społeczna itd., każdorazowo wymaga merytorycznego przygotowania ze strony badacza, tak aby można było każdorazowo, w zależności od tematyki, stworzyć szczegółową strukturę wywiadu.

Celem badacza w trakcie wywiadu jest uzyskanie informacji definiowanych jako obiektywne fakty lub autentyczne, choć subiektywne, znaczenia, poprzez

4 Bardzo dziękujemy koleżankom i kolegom z Ośrodka „Pamięć i Przyszłość” oraz prof. Joannie Wojdon i dr. Łukaszowi Kamińskiemu z Uniwersytetu Wrocławskiego za inspirującą i ważną dla nas dyskusję podczas seminarium zorganizowanego przez Ośrodek w listopadzie 2020 r. Pod wpływem pytań, uwag i sugestii, które padły z ust praktyków historii mówionej i historyków dziejów najnowszych, uzupełniliśmy i doprecyzowaliśmy kilka istotnych wątków.

5 S. Kvale, op. cit., s. 37. 
umożliwienie respondentowi (świadkowi, informatorowi) ${ }^{6}$, w takim zakresie, w jakim pozwala mu na to kontakt w badaniư oraz osobiste granice i potrzeby:

a. sięgnięcia do zdarzeń, których był aktywnym uczestnikiem lub obserwatorem,

b. opowiedzenia o nich z jego perspektywy ${ }^{8}$.

W efekcie badacz otrzymuje informacje o przeszłości wraz z osobistym odniesieniem respondenta. Jest ono odbiciem wiedzy, przekonań i doświadczeń, które tworzą jego/jej osobową i społeczno-kulturową tożsamość oraz profesjonalnej relacji z badaczem, która umożliwia (bardziej lub mniej) ujawnienie tej osobistej perspektywy.

Nie tylko samo przeszłe zdarzenie lub czas, ale również doświadczenia z przeszłości dzisiaj przez respondenta odtwarzane oddają to, czym było dla niego to zdarzenie lub okres. Tym samym przyczyniają się do lepszego zrozumienia tych zdarzeń.

Traktowanie przez wielu historyków z rezerwą nie tylko ustnych relacji wspomnieniowych, ale w ogóle „źródeł wywołanych”, dotyczy głównie kwestii "zawodności pamięci” i związanej z nią „wiarygodności” źródła. Wiarygodność nie jest jednak pojęciem psychologicznym i nie odnosi się do wspomnień. Relacje świadków historii - tak jak relacje świadków w procesie sądowym - należy oceniać, rozstrzygając, czy mają oparcie w osobistych śladach pamięciowych'. O tym, jakie jest prawdopodobieństwo, że informacje zawarte w relacji odzwierciedlają rzeczywiste zdarzenia (czy wspomnienia są trafne czy nie), decyduje ocena historyka dokonana w toku analizy, czyli już po wywiadzie. Historyk dokonuje jej za pomocą różnych dostępnych w swojej dyscyplinie narzędzi, takich jak zestawianie danych z różnych źródeł, konfrontacja źródeł i dogłębna analiza danych.

Pamięć to zarówno indywidualna zdolność podmiotu, wyposażenie jednostki (zwykliśmy mówić, że ktoś ma „dobrą pamięć”), jak i proces poznawczy. W drugim znaczeniu pamięć „działa”, przetwarzając informacje w fazach kodowania, przechowywania i odtwarzania. Fazy te angażują wiele różnych procesów poznawczych i prowadzą od spostrzeżeń i kodowania informacji, przez przechowywanie i rekodowanie na podstawie nowych, napływających informacji, do poszukiwania

6 Nie posługujemy się określeniem „rozmówca” ani „narrator”, ponieważ terminy te leżą w domenie poznawczej „badaczy-podróżników”.

7 Kontakt w badaniu (rapport) - pojęcie odnosi się do jakości relacji badawczej, która opiera się na zaufaniu i szacunku w bezpiecznych i komfortowych warunkach, pozwalającej dzielić się osobistymi doświadczeniami i postawami. Zob.: D.L. Morgan, H. Guevara, Rapport, [w:] The SAGE Encyclopedia of Qualitative Research Methods, red. L.M. Given, Sage 2008, s. 728-729.

8 W związku z tym, że narracja jest społeczną formą konstruowania wspomnień autobiograficznych, perspektywa ta powinna uwzględniać też język opracowania zdarzeń i doświadczeń dostępny w domenie dyskursu. 
informacji w pamięci długotrwałej (odtwarzanie) oraz decyzji dotyczącej na przykład tego, co i jak opowiedzieć podczas wywiadu. Szukając odpowiedzi na pytanie, jak rozmawiać o przeszłości, należy w związku z tym sięgać w szczególności do naukowej wiedzy na temat pamięci zdarzeń (tj. pamięci epizodycznej), pamięci autobiograficznej i procesów przeszukiwania i wydobywania informacji z pamięci długotrwałej ${ }^{10}$.

Pamięć epizodyczna to pamięć zdarzeń mających konkretną lokalizację czasową i przestrzenną. Nie reprezentuje ona faktów, pojęć i relacji między nimi (to właściwość tzw. pamięci semantycznej), ale uporządkowane czasowo zdarzenia, często powiązane z osobistą przeszłością osoby opowiadającej. Pamięć epizodyczna ma charakter świadomy i dowolny, a odtworzenie z niej informacji niekiedy wymaga wysiłku. Ponadto jest autonoetyczna, czyli osoba ma subiektywne poczucie, że wspomnienie jest jej własnym doświadczeniem ${ }^{11}$. Pamięć autobiograficzna, ogólnie mówiąc, jest zapisem historii życia czy dotychczasowym osobistym doświadczeniem życiowym ${ }^{12}$. Obejmuje fakty z przeszłości danej osoby oraz jej wspomnienia zdarzeń zarówno z perspektywy aktora, jak i obserwatora. Zawiera odniesienia do pamięci semantycznej (np. wiedzy o miejscowości we Włoszech, w której się było na wakacjach) i epizodycznej (np. o pobycie na wakacjach w tej miejscowości we Włoszech), a niekiedy także uznaje się, że zawiera również informacje proceduralne (np. o tym, jak rozstawić namiot). To, co czyni ją specyficzną, to bezpośrednie odniesienia do pojęcia Ja oraz do tożsamości podmio$\mathrm{tu}^{13}$. Informacje związane $\mathrm{z}$ Ja są zawsze lepiej pamiętane od tych niezwiązanych, a szczególną rolę odgrywają tu cele osobiste. Hierarchia celów osoby działa jak zbiór procesów kontroli poznawczej i jest wyznacznikiem kodowania, dostępu do wiedzy z pamięci długotrwałej i tworzenia wspomnien ${ }^{14}$. Ludzie zatem często opowiadają o zdarzeniach ze swojej perspektywy, co oznacza dodatkowo zaprzęganie własnych motywów, a nie bezstronne referowanie przebiegu zdarzeń.

Można bardzo ogólnie wskazać, że pamięć autobiograficzna to przedmiot zainteresowań „badaczy-podróżników”, podczas gdy „górnicy” kierują swoją uwagę ku temu, co znajduje się w pamięci epizodycznej.

10 Por. np.: T. Maruszewski, Pamięć autobiograficzna - nowe dane, „Neuropsychiatria i Neuropsychologia", t. 5 (2010), nr 3-4, s. 122-129; M. Jagodzińska, Psychologia pamięci. Badania, teorie, zastosowania, Gliwice 2008.

11 E. Tulving, Episodic memory: from mind to brain, „Annual Review of Psychology”, t. 53 (2002), s. 1-25.

12 Zob.: M. Jagodzińska, op. cit.; T. Maruszewski, op. cit.

13 Por.: A. Gilboa, S. Rosenbaum, A. Mendelsohn, Autobiographical memory: from experiences to brain representations, „Neuropsychologia”, t. 110 (2018), s. 1-6; S.B. Klein, Self, memory, and the self-reference effect: an examination of conceptual and methodological issues, „Personality and Social Psychology Review", t. 16 (2012), s. 283-300. Zob.: A. Gilboa, S. Rosenbaum, A. Mendelsohn, op. cit. 
Jako badacze możemy zadbać, aby wywiad, respektując prawa działania pamięci, dostarczał najlepszego możliwego materiału historycznego. Ze względu na właściwości pamięci epizodycznej i autobiograficznej (której pamięć epizodyczna jest ważnym aspektem), warto wyróżnić dwa zjawiska, które mogą wpłynąć na jakość uzyskanego materiału ${ }^{15}$ :

1. pamięć jest częściowo reprodukcyjna, tzn. przechowuje detale specyficzne dla zdarzeń, więc możemy oczekiwać pewnej trafności sprawozdań naocznych świadków zdarzeń;

2. pamięć jest częściowo rekonstrukcyjna, a ten twórczy aspekt jest obecny:

a. na etapie spostrzegania (gdy najpierw sensorycznie tworzone są dane pamięciowe),

b. na etapie włączania spostrzeżeń w istniejące już schematy (np. jak wygląda zwykle pobyt w restauracji, czy jaką ktoś ma wizję świata społecznego, np. „ludzie są nieprzyjaźni", i jak dalece nowe doświadczenia mogą to zmienić),

c. na etapie zmian zawartości pamięci w toku uczestnictwa w kolejnych zdarzeniach (rekodowanie),

d. na etapie odtwarzania zdarzeń (podczas przypominania sobie, spisywania czy opowiadania).

Jeśli zdarzenia z przeszłości są złożone lub wieloznaczne, to schematy wpływają na przywoływanie, prowadząc niekiedy nawet do żywych wspomnień, ale fałszywych. W efekcie słyszymy w wypowiedziach materiał spójny ze schematami ${ }^{16}$. Na łatwość zapamiętywania wpływa wiele czynników, ale spośród tych indywidualnych wymienia się poziom pobudzenia emocjonalnego w chwili zdarzenia (silne pobudzenie zawęża pole uwagi - osoba spostrzega mniej z tego, co dookoła niej się dzieje; umiarkowane pobudzenie, będące elementem reakcji orientacyjnej, sprzyja zapamiętywaniu większej ilości szczegółów) oraz stopień zgodności zdarzenia ze schematami poznawczymi (łatwiej zapamiętać informacje zgodne ze schematem, ponieważ pozwala on interpretować dane percepcyjne $)^{17}$.

\section{Procedury}

Proponowaną metodę pod względem praktycznym dookreślają rola badacza i osoby uczestniczącej w badaniu (respondenta, świadka), a także łącząca ich relacja oparta na profesjonalizmie badacza.

15 Por.: A. Niedźwieńska, Poznawcze mechanizmy zniekształceń w pamięci zdarzeń, Kraków 2004 .

16 Por.: C.R. Brewin, B. Andrews, L. Mickes, Regaining Consensus on the Reliability of Memory, „Current Directions in Psychological Science”, t. 29 (2020), nr 2, s. 121-125.

17 Zob.: T. Maruszewski, op. cit. 
O naukowej jakości, czyli przydatności badawczej materiału uzyskiwanego drogą wywiadu decydują: umiejętne „zakontraktowanie” badania oraz umiejętności komunikacyjne badacza.

\section{Zakontraktowanie badania}

Kontrakt dotyczący wywiadu to uzgodnienie z respondentem warunków rozmowy, za które odpowiada badacz, inicjujący i przeprowadzający negocjacje. W treści tej umowy (nagranej i ewentualnie spisanej, tak by każda ze stron mogła się odwołać do uzgodnień) badacz:

a. prezentuje postawę profesjonalną, która polega na tym, że nie wychodzi poza swoją rolę, oraz etyczną, polegającą na tym, że relacja w czasie wywiadu oparta jest na zaufaniu;

b. uzyskuje świadomą zgodę respondenta na badanie, nagranie i wykorzystanie materiału w pracy naukowej;

c. proponuje zasady i możliwości anonimizacji i/lub autoryzacji oraz przechowywania i udostępniania materiału uzyskanego od respondenta;

d. wyjaśnia wszelkie wątpliwości respondenta związane z badaniem;

e. wyraża gotowość poddania treści kontraktu negocjacjom w ramach dopuszczalnych w danym projekcie badawczym, lub rezygnacji z wywiadu, jeśli dalej idące negocjacje nie są możliwe.

Kontrakt jest kluczowy dla metody wywiadu, ponieważ profesjonalizuje relację między historykiem i respondentem. Werbalizując swoje role w badaniu, obie strony chronią się przed niepożądanymi sytuacjami, z których najczęstsze w sytuacji wywiadu to powstanie relacji quasi-terapeutycznej lub relacji „fałszywej przyjaźni", albo też manifestowanie przez badacza swojego światopoglądu (autentycznego lub przybranego pod wpływem świadka).

Ponadto na etapie zawierania kontraktu na badanie historyk ujawnia respondentowi sposób powiązania wywiadu z celami badawczymi, w szczególności fundamentalny poznawczo zabieg splatania chronologii osobistej ${ }^{18}$ i obiektywnej (co będzie miało przełożenie na konkretne pytania w wywiadzie). Precyzyjne sformułowanie oczekiwań historyka pomaga z kolei respondentowi skupić uwagę i, przyjmując pozycję bohatera sytuacji, przywoływać doświadczenia z przeszłości.

Kontraktowanie badania składa się z trzech etapów:

I. rozmowy wstępnej (o charakterze nieformalnym i niewiążącym; przed nagraniem);

II. wstępu (przed nagraniem);

III. właściwego kontraktu (nagranie ustaleń osób biorących udział w wywiadzie). 
Poniższa tabela zestawia zasadnicze cele etapów kontraktowania, sposoby ich realizacji oraz przykłady przetestowanych sformułowań.

Tabela 1. Cele, sposoby ich realizacji i propozycje sformułowań na trzech etapach kontraktowania badania.

\begin{tabular}{|c|c|c|c|}
\hline Etap & Cele & Sposoby realizacji celów & $\begin{array}{l}\text { Przetestowane propozycje } \\
\text { sformułowań }\end{array}$ \\
\hline 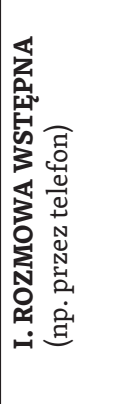 & $\begin{array}{l}\text { - Zbudowanie profesjonalnej } \\
\text { relacji pomiędzy badaczem } \\
\text { (historykiem) i jego } \\
\text { rozmówcą; } \\
\text { - Powiązanie } \\
\text { specyfiki wywiadu } \\
\text { i rekonstruowania } \\
\text { przeszłości za pomocą } \\
\text { pamięci z celami badań } \\
\text { historycznych. }\end{array}$ & $\begin{array}{l}\text { - Autoprezentacja } \\
\text { badacza: podanie afiliacji } \\
\text { i określenie dyscypliny, } \\
\text { w jakiej mieszczą się } \\
\text { prowadzone badania; } \\
\text { - Przedstawienie przedmiotu } \\
\text { i celu badań; } \\
\text { - Informacja na temat } \\
\text { zamiaru rejestracji } \\
\text { wywiadu. }\end{array}$ & $\begin{array}{l}\text { - Chociaż rozmowa ma } \\
\text { charakter nieformalny, } \\
\text { wymaga użycia } \\
\text { precyzyjnych określeń, } \\
\text { np.: } \\
\text { - „Jestem historykiem, } \\
\text { pracownikiem instytucji } \\
\text { X”; } \\
\text { - „Realizuję projekt } \\
\text { badawczy pod tytułem..., } \\
\text { którego celem jest...”. }\end{array}$ \\
\hline \multirow{3}{*}{ 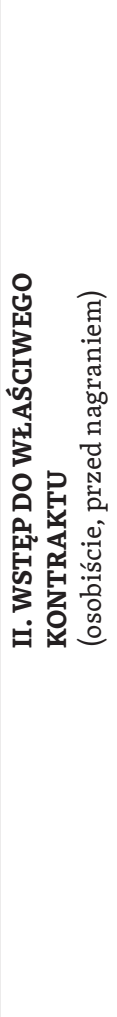 } & \multirow[t]{3}{*}{$\begin{array}{l}\text { - Zapewnienie komfortu } \\
\text { respondentowi; } \\
\text { - Zbudowanie atmosfery } \\
\text { zaufania pomiędzy } \\
\text { rozmówcami; } \\
\text { - Upodmiotowienie } \\
\text { rozmówcy. }\end{array}$} & $\begin{array}{l}\text { - Nawiązanie do ustaleń } \\
\text { rozmowy wstępnej; } \\
\text { - Wprowadzenie do } \\
\text { zakontraktowania } \\
\text { (w jednym, maksymalnie } \\
\text { dwóch zdaniach); } \\
\text { - Podanie tylko } \\
\text { najważniejszych, } \\
\text { niezbędnych dla dalszego } \\
\text { toku rozmowy informacji. }\end{array}$ & $\begin{array}{l}\text { - „Bardzo dziękuję, że } \\
\text { zgodził(a) się Pan(i) na tę } \\
\text { rozmowę. } \\
\text { - Czy nie zmienił(a) Pan(i) } \\
\text { zdania? } \\
\text { - Przed rozpoczęciem } \\
\text { chciał(a)bym poświęcić } \\
\text { kilka chwil na wyjaśnienie, } \\
\text { dlaczego poprosiłem/łam } \\
\text { o ten wywiad, przedstawić, } \\
\text { jak będzie on mniej } \\
\text { więcej wyglądał. I przede } \\
\text { wszystkim ustalić zasady } \\
\text { jego wykorzystania”. }\end{array}$ \\
\hline & & $\begin{array}{l}\text { - Zaznaczenie prawa } \\
\text { rozmówcy do negocjowania } \\
\text { lub kwestionowania } \\
\text { proponowanych rozwiązań. }\end{array}$ & $\begin{array}{l}\text { - „Jeśli będzie miał(a) Pan(i) } \\
\text { jakiekolwiek pytania albo } \\
\text { wątpliwości, proszę o ich } \\
\text { zasygnalizowanie, dobrze?” }\end{array}$ \\
\hline & & $\begin{array}{l}\text { Przejście do fazy } \\
\text { nagrywania: prośba } \\
\text { o wyrażenie zgody na } \\
\text { włączenie rejestratora } \\
\text { dźwięku lub dźwięku } \\
\text { i obrazu. }\end{array}$ & $\begin{array}{l}\text { - „Chciał(a)bym też już } \\
\text { teraz włączyć dyktafon. } \\
\text { Tak żeby nagrało się } \\
\text { też moje wyjaśnienie } \\
\text { i ustalone wspólnie zasady } \\
\text { wykorzystania. Czy nie ma } \\
\text { Pan(i) nic przeciw temu?” }\end{array}$ \\
\hline
\end{tabular}




\begin{tabular}{|c|c|c|c|}
\hline \multirow[t]{2}{*}{ 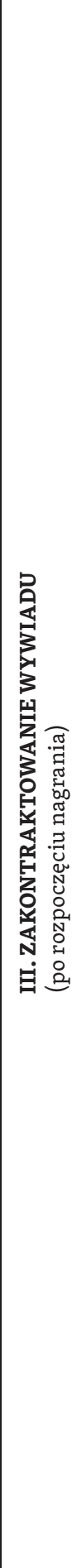 } & \multirow[t]{2}{*}{$\begin{array}{l}\text { - Zbudowanie profesjonalnej } \\
\text { relacji pomiędzy badaczem } \\
\text { (historykiem) i jego } \\
\text { rozmówcą; } \\
\text { - Ustalenie jasnych } \\
\text { i zrozumiałych dla } \\
\text { rozmówcy zasad } \\
\text { prowadzenia wywiadu } \\
\text { oraz wykorzystania } \\
\text { zarejestrowanego } \\
\text { materiału; } \\
\text { - Powiązanie wywiadu } \\
\text { z celami badawczymi } \\
\text { historyka; } \\
\text { - Powiązanie } \\
\text { chronologii osobistej } \\
\text { i ponadindywidualnej } \\
\text { w sposób jawny oraz } \\
\text { zrozumiały dla rozmówcy; } \\
\text { - Upodmiotowienie } \\
\text { rozmówcy; } \\
\text { - Stworzenie warunków, } \\
\text { umożliwiających } \\
\text { zrozumienie przez } \\
\text { respondenta celów } \\
\text { prowadzonego badania; } \\
\text { - Generowanie sytuacji } \\
\text { mentalnego „zanurzenia” } \\
\text { (immersji) w danym } \\
\text { okresie w przeszłości. }\end{array}$} & $\begin{array}{l}\text { - Opis charakteru badań i ich } \\
\text { celów; } \\
\text { - Wyjaśnienie związku } \\
\text { konkretnego wywiadu } \\
\text { z całością prowadzonych } \\
\text { badań (dlaczego } \\
\text { zwróciliśmy się właśnie do } \\
\text { tej osoby); } \\
\text { - Sprawne powiązanie } \\
\text { przedmiotu badań } \\
\text { z chronologią życia naszego } \\
\text { rozmówcy. To szczególnie } \\
\text { ważne działanie przebiega } \\
\text { w } 3 \text { krokach: } \\
\text { 1) odwołanie do etapu } \\
\text { w życiu rozmówcy, } \\
\text { istotnego jako fragment } \\
\text { cyklu życia, który można } \\
\text { umieścić w obiektywnej, } \\
\text { zewnętrznej chronologii } \\
\text { (ujętej datami wydarzeń, } \\
\text { które mają potwierdzenie } \\
\text { w dokumentach, np. } \\
\text { przebieg edukacji, zawarcie } \\
\text { małżeństwa, pobyt } \\
\text { w wojsku etc.); } \\
\text { 2) odwołanie do bardziej } \\
\text { ogólnych zagadnień, } \\
\text { istotnego badawczo } \\
\text { procesu/zjawiska; } \\
\text { 3) podsumowanie: } \\
\text { związanie dwóch } \\
\text { zarysowanych wcześniej } \\
\text { kroków. }\end{array}$ & $\begin{array}{l}\text { - Przykład wywiadu } \\
\text { z byłym studentem historii } \\
\text { (ur. } 1971 \text { r.), obecnie } \\
\text { pracownikiem naukowym } \\
\text { UJ.: } \\
\text { „Poprosiłem o tę rozmowę, } \\
\text { bo jak wiem, 1) zaczął } \\
\text { Pan studia na przełomie } \\
\text { lat 8o i go. 2) Jestem } \\
\text { historykiem i w badaniach, } \\
\text { które obecnie prowadzę, } \\
\text { zajmuję się pokoleniem } \\
\text { ludzi, którzy w dorosłość } \\
\text { wchodzili pod koniec } \\
\text { lat } 80 . \text { i na początku } \\
\text { kolejnej dekady.3) } \\
\text { Szczególnie interesuje } \\
\text { nas właśnie sam moment } \\
\text { wchodzenia w dorosłość, } \\
\text { który przypada na okres } \\
\text { studiów”. }\end{array}$ \\
\hline & & $\begin{array}{l}\text { - Zarysowanie charakteru } \\
\text { wywiadu, a także } \\
\text { oczekiwań wobec } \\
\text { respondenta; } \\
\text { - Wskazanie na związek } \\
\text { pytań z prowadzonymi } \\
\text { badaniami; } \\
\text { - „Zanurzenie” w przeszłości } \\
\text { poprzez bodziec } \\
\text { początkowy. }\end{array}$ & $\begin{array}{l}\text { - „Wywiad może czasami } \\
\text { przypominać luźną } \\
\text { rozmowę, nie jest } \\
\text { prowadzony wedlug } \\
\text { ścisłego kwestionariusza. } \\
\text { - Chociaż jednocześnie będę } \\
\text { chciał(a) zadać szereg } \\
\text { pytań, które są dla mnie } \\
\text { ważne z punktu widzenia } \\
\text { prowadzonych badań. } \\
\text { Nie znaczy to, że wywiad } \\
\text { będzie przesłuchaniem. } \\
\text { Zależy mi przede } \\
\text { wszystkim na tym, } \\
\text { by spróbował(a) się } \\
\text { Pan(i) wczuć w siebie } \\
\text { w tamtym czasie; jestem }\end{array}$ \\
\hline
\end{tabular}


też otwarty/a na Pana/i opinie, spostrzeżenia. Co więcej - bardzo prawdopodobne, że pod ich wpływem ulegną zmianie przygotowane przeze mnie pytania i przyjęte założenia". wywiadu: pojedyncze spotkanie nie może trwać dłużej niż 1-1,5 godz. (patrz pkt 2. Umiejętności komunikacyjne).

- Przyjęcie postawy szacunku wobec granic respondenta: podkreślenie, że ma prawo do odmowy odpowiedzi, może też poprosić o zmianę tematu.
- „Rozmowa będzie trwała około godziny, na pewno nie dłużej niż 1,5 godz."
- „Może też się zdarzyć, że zadam pytania, na które nie będzie chciał(a) Pan(i) odpowiadać. Proszę skorzystać wówczas z prawa odmowy odpowiedzi. Możemy też wtedy po prostu zmienić temat.

- Gdyby nasunęło się Panu/i w trakcie coś ważnego, a ja nie zadam o to pytania, proszę dać mi znać, dobrze?"

- Po podaniu serii informacji przez prowadzącego wywiad konieczne jest upewnienie się, że są one zrozumiałe dla rozmówcy. Pytanie to odgrywa również rolę pauzy przed przejściem do kwestii wykorzystania nagranego materiału. Upewnianie się, że zostaliśmy dobrze zrozumiani i zyskiwanie aprobaty rozmówcy dla proponowanych przez badacza kolejnych kroków jest ważne w toku całego wywiadu, a szczególną rolę odgrywa właśnie na etapie kontraktowania (zob. Załącznik 1).
- „Czy wszystko jest do tej pory jasne?” 


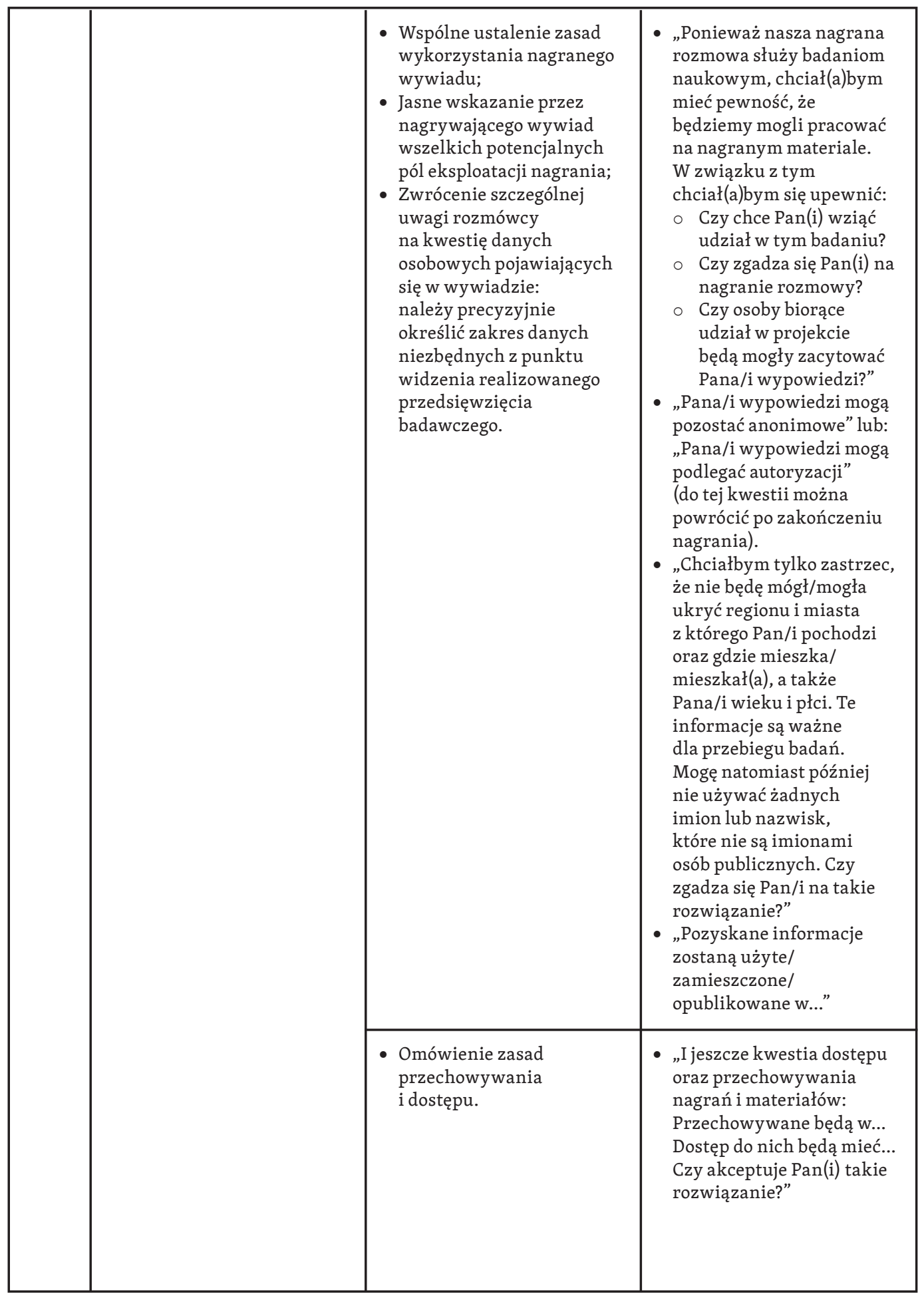




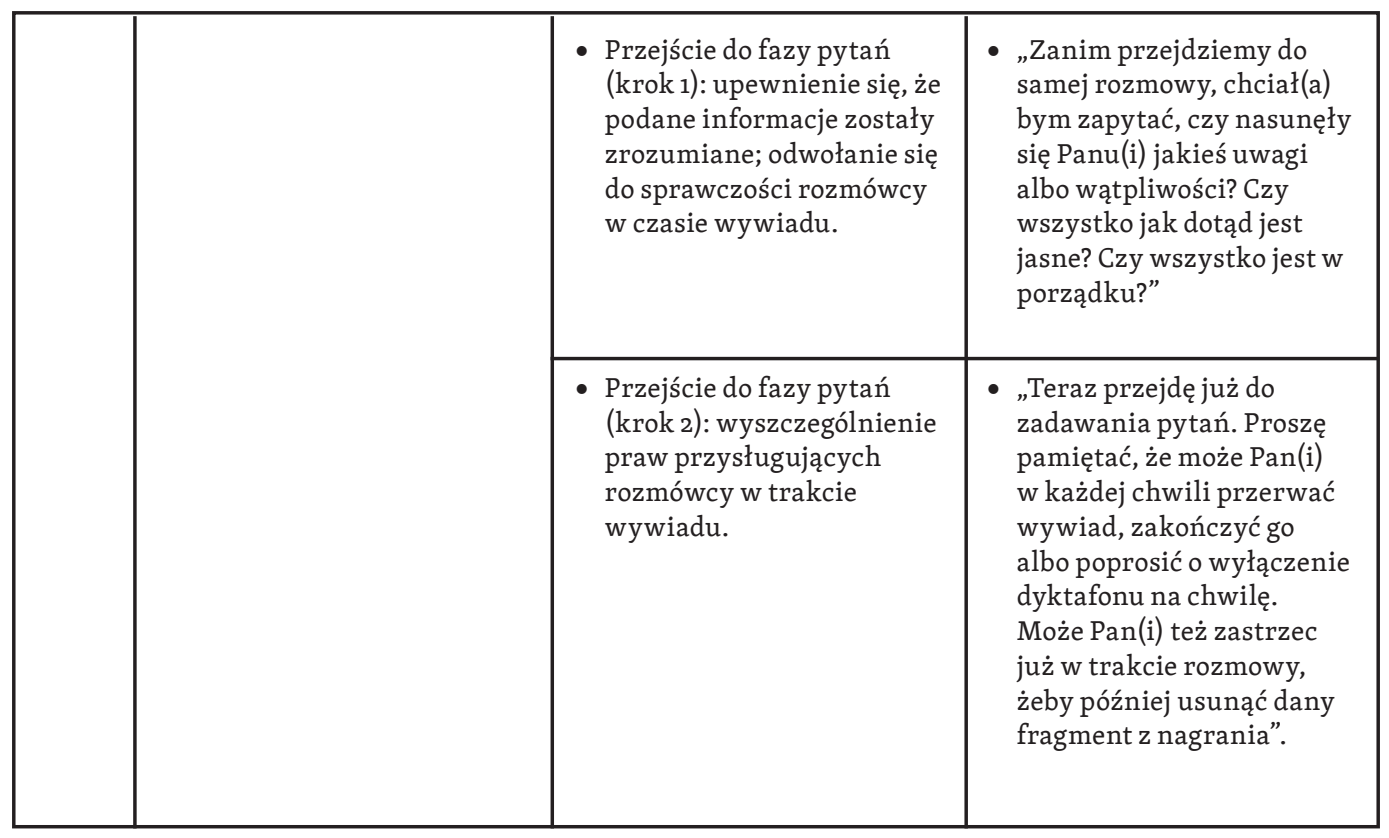

\section{Umiejętności komunikacyjne}

Podczas wywiadu badacz porusza się pomiędzy postawą biernego słuchacza swobodnej opowieści o zdarzeniu a zadawaniem określonych pytań, które wynikają z tematu badań i rozwiązywanego problemu badawczego. Regułą każdego wywiadu częściowo ustrukturyzowanego jest bowiem to, że prowadzący pozostaje otwarty na to, co pojawia się w odpowiedziach respondenta, jest w stanie zmieniać kolejność pytań lub stawiać nowe, ale nadal kontroluje tok rozmowy.

Podkreślmy, że w proponowanej metodzie umiejętności komunikacyjne badacza służą wspieraniu odtwarzania wspomnień, czyli uzyskaniu dostępu do pamięci respondenta oraz tworzeniu etycznej relacji interpersonalnej. Ta ostatnia zaś również sprzyja przypominaniu.

Mając na uwadze przedstawione wyżej ustalenia psychologów, część komunikacyjną wywiadu podzieliliśmy na trzy główne fazy:

I. Bodziec początkowy - pytanie/sekwencja pytań otwierających wywiad;

II. Prowadzenie wywiadu - utrzymywanie komunikacji;

III. Zamknięcie sytuacji badawczej.

Tak jak przy kontraktowaniu badania, tak i na początku wywiadu, dobrze jest powtórzyć - ale nie więcej niż jeden raz - sformułowanie "jestem historykiem”. Jest to sygnał dla rozmówcy, że interesują nas wiedza i autentyzm wspomnień. Warto jednak przy tym dodać, że jesteśmy świadomi, że pamięć bywa niekiedy 
zawodna. Taka rozmowa o pamięci określa relację interpersonalną, sytuuje nas w roli badaczy zbierających dane (a nie np. terapeutów), a przy tym nie wyrażamy nadmiernych oczekiwań co do funkcjonowania pamięci respondentów (które mogłyby ich przytłoczyć $)^{19}$.

Faza I. Bodziec początkowy - pytanie/sekwencja pytań otwierających wywiad. Bodziec początkowy to pytanie (pytania) otwierające, kluczowe dla całej rozmowy, bo w sensie merytorycznym wyznacza ono ścieżkę całego kwestionariusza i komunikacji w wywiadzie. Zastosowany zostaje w nim zabieg, który został juź zasygnalizowany rozmówcy na etapie kontraktowania wywiadu: na poziomie pytań wywiad powiąże chronologię cyklu życia jednostki z chronologią zjawisk, zdarzeń i procesów o charakterze ponadindywidualnym.

W proponowanym modelu spełnione muszą być dwa warunki:

1) pytanie otwierające nie może być pytaniem o całą biografię (jak pytanie: „Proszę opowiedzieć mi o swoim życiu”);

2) wywiadu nie może otwierać pytanie o konkretne wydarzenie/zjawisko o dużym zasięgu lub funkcjonujące w dyskursie jako historycznie znaczące (np. „Jak Pan(i) pamięta przemiany 1989 roku?").

Paradoksalnie rozmówcy może być trudno zlokalizować w pamięci wydarzenia/zjawiska, o których mowa powyżej, i rozpocząć od nich autonarrację, a to, co jest oczywiste dla historyka, nie musi być takie dla respondenta. Jeśli dodatkowo badany dostał instrukcję, że interesują nas jego osobiste losy i wspomnienia, to może nie wiedzieć, jak w obliczu „wielkiej historycznej daty” powinien zacząć. Takie pytanie może też zostać odebrane jako wyraz oczekiwania badacza na jakąś generalną opinię rozmówcy o danym wydarzeniu/zjawisku. Nie chodzi tu też o bezpośrednie pytanie o osobiste doświadczenie zjawiska historycznego - wtedy wkraczamy w pole pamięci autobiograficznej i trudno będzie się z tego w trakcie rozmowy wycofać.

$\mathrm{Na}$ otwarcie wywiadu rekomendujemy pytanie odnoszące się do etapu w życiu respondenta maksymalnie zbliżonego do interesujących badacza zagadnień (o znaczeniu ponadindywidualnym), ale zawsze od nich wcześniejszego. Testując metodę w badaniu na temat pokolenia młodzieży okresu transformacji ustrojowej w Polsce, osobom, które w tamtym czasie rozpoczynały studia, jako pierwsze zadawano pytanie o moment rozpoczęcia nauki w szkole średniej. Sekwencja otwierająca wyglądała następująco:

19 Badacz jasno mówi, że chce usłyszeć autentyczne wspomnienia, ale wie, że pamięć jest zawodna, rozmówca zaś dostaje znak, że badacz nie chce słuchać wszystkiego, co rozmówca wie na jakiś temat (pamięć semantyczna), ale tylko to, czego ślad pamięciowy został wytworzony w określonym czasie. Wiedząc, że badacz akceptuje fakt zawodności pamięci, rozmówcy łatwiej przyjdzie powiedzieć „nie pamiętam”. 
Prowadzący wywiad: Od razu przejdę do interesującego mnie okresu... zacznę od liceum, dobrze? Czy liceum to był świadomy wybór? Jak do tego doszło?

Zabieg ten pomaga precyzyjnie skorelować początek wywiadu z osobistą osią czasu respondenta i ułatwia mu możliwie komfortowe uruchomienie autonarracji. Jest też zrozumiały dla rozmówcy, bo dystans czasowy poruszonych w pierwszym pytaniu wydarzeń wobec przedstawionych wcześniej celów badawczych jest niewielki. Co więcej pomaga on badaczowi w określeniu chronologii bezwzględnej opowieści, czyli dat (więcej na ten temat poniżej).

Faza II. Prowadzenie wywiadu - utrzymywanie komunikacji.

W dalszej części wywiadu podstawowe znaczenie mają dwie umiejętności badacza: 1) przekształcania pytań badawczych w pytania w wywiadzie oraz 2) wspierania odtwarzania wspomnień przez respondenta. Ta pierwsza kwestia to kontynuacja zabiegu stosowanego podczas pytania otwierającego, tzn. wiązania osobistych doświadczeń rozmówcy z szerszym kontekstem.

Jak już wspominaliśmy, pamięć epizodyczna, do której badacz tutaj się odwołuje, charakteryzuje się tym, że niekiedy potrzeba sporego wysiłku, aby przywołać konkretne zdarzenie. Rolą badacza jest pomoc rozmówcy w dojściu do wspomnienia metodą kolejnych przybliżeń, po nitce do kłębka. W takiej sytuacji zadaniem badacza wspierającego odtwarzanie zdarzeń przez respondenta będzie uzyskanie dostępu do tzw. ramy konceptualnej ${ }^{20}$. Robimy to, np. zarysowując okoliczności wydarzenia/zjawiska i w ten sposób wprowadzając respondenta w sytuację, którą ma wspominać ${ }^{21}$. Komunikujemy przy tym, że wspomnienie może być trudne do przywołania i że zależy nam na trafnym przywołaniu ${ }^{22}$, ale staramy się nie naciskać

M.A. Conway, Episodic memories, „Neuropsychologia”, t. 47 (2009), nr 11, s. 2305-2313.

Przykładem takiego wspomagania pamięci może być następująca sytuacja w badaniu, którego celem było przywołanie wspomnień o okresie transformacji ustrojowej w Polsce. Badacz znając wiek respondentki, pyta o jej drogę do szkoły podstawowej: jakim środkiem transportu się do niej dostawała? Ponieważ pada odpowiedź, że pieszo, badacz pyta, czy respondentka może zrekonstruować tę drogę etap po etapie, zachęcając do swoistego „przeniesienia się" do tamtego czasu i przestrzeni. Wysiłek pamięci respondentki wspomagany jest drobnymi pytaniami np. o to, czy szły z nią koleżanki, czy trzeba było pokonać ruchliwą ulicę, czy były przy niej światła, czy na skwerach stały slogany propagandowe. W pewnym momencie respondentka przypomina sobie, nie tylko przetrzeń i slogan propagandowy, ale i wydarzenie, które osadza w drugiej połowie czerwca 1989 roku - zachlapanie farbą sloganu.

22 Trafność przywołania badacz może sprawdzić kolejnymi pytaniami, po których rozmówca sam siebie koryguje i ma świadomość, że wspomnienie/obraz zaczyna komponować się z większej ilości detali, których źródła może podać albo wyjaśnić (np. hasło partyjne widniało po drodze do przedszkola zimą danego roku, ale nie było go już w roku następnym. Rozmówca pamięta to, bo chodził wtedy do przedszkola w zimowych butach, które nie chciały się ślizgać na ślizgawce obok tego hasła, a te buty na pewno dostał na gwiazdkę tego roku, co widać na tym zdjęciu itp., itd.). 
nadmiernie na ten aspekt, ponieważ ryzykujemy otrzymaniem ograniczonej ilości informacji ${ }^{23}$.

Aby wesprzeć lepsze odtwarzanie zdarzenia, warto skierować uwagę respondenta kolejno: na zapamiętane myśli (np. „co Pan(i) pomyślał(a)?”) i uczucia (np. „co Pan(i) poczuł(a)?”), lokalizację przestrzenną zdarzenia (np. „w jakim to było miejscu?”), czas (np. „jaka to była pora dnia?”), sekwencje epizodu (np. „co działo się przed tym wydarzeniem?”; „co działo się po tym wydarzeniu”) ${ }^{24}$. Te detale i okoliczności mogą stanowić bodźce do dalszego przypominania. Dobrym wskaźnikiem tego, że rozmówcy udało się wczuć w sytuację i aktywować ślady pamięciowe zapisane w kodzie obrazowym (np. wspomnienia wyglądu osób, zapachu), jest poczucie „zanurzenia” (imersji) w zdarzeniu, o którym to poczuciu respondent może powiedzieć sam z siebie lub o które możemy dopytać po każdym wątku.

Elementy fazy komunikacji, które bezpośrednio wspierają odtwarzanie śladów pamięciowych, to zadawanie pytań i dopytywanie o szczegóły (w zasadzie każde pytanie zapisane w kwestionariuszu wymaga takiego dopytania). Zbyt duża ilość zmiennych (jak specyfika tematu badania, osobowości i kompetencje komunikacyjne uczestników wywiadu oraz niemożliwe do przewidzenia sytuacje powstałe podczas rozmowy) uniemożliwia przedstawienie tu szczegółowej instrukcji postępowania, niemniej wiedza z zakresu funkcjonowania pamięci pozwala na wskazanie pewnych zasad, których zastosowanie sprzyjać będzie sięganiu do śladów w pamięci epizodycznej. Ważnym ujęciem teoretycznym jest tu koncepcja Martina A. Conwaya (Self-Memory System) ${ }^{25}$, według której pamięć

23 Zob.: A. Niedźwieńska, op. cit. Badania sugerują, że jeśli dodamy, że zależy nam na trafnych wspomnieniach, prawdopodobnie uzyskamy rzeczywiście więcej faktów, ale zahamujemy spontaniczność odtwarzania, wczuwanie się i dzielenie się swoim światem (zob. M. Goldsmith, A. Koriat, The strategic regulation of memory accuracy and informativeness, „Psychology of Learning and Motivation”, t. 48 (2007), s. 1-60, za: T. Maruszewski, op. cit.). Nie znaczy to, naszym zdaniem, że jesteśmy skazani - jako historycy (badacze-górnicy) na binarną sytuację poznawczą (tzn. dostajemy albo fakty, albo osobistą narrację). Zob.: T. Rakowski, Historia mówiona i źródła etnograficzne jako „wiedza pewna”. Przypadek potransformacyjnej historii Torgutów w zachodniej Mongolii oraz historii wsi Broniów w centralnej Polsce, „Rocznik Antropologii Historii”, t. 5 (2015), s. 59-90; P. Filipkowski, Historia mówiona jako historia faktyczna albo jak „odantropologizować” opowieści o przeszłości?, „Rocznik Antropologii Historii”, t. 5 (2015), s. 91-108; M. Stasiak, „Czy więc byliśmy i jesteśmy naiwni...?” Jeszcze jeden głos $w$ debacie nad wykorzystaniem relacji ustnych $w$ badaniach najnowszej historii Polski, „Wrocławski Rocznik Historii Mówionej”, t. 8 (2018), s. 29-61; P. Filipkowski, M. Kurkowska-Budzan, T. Rakowski, M. Stasiak, Reanimacje i rewitalizacje - relacje ustne jako czynnik innowacji w badaniach historycznych. Głosy w dyskusji, „Rocznik Antropologii Historii", t. 12 (2019), s. 311-320. Zob.: A. Niedźwieńska, op. cit.

25 M.A. Conway, C. Loveday, Remembering, imagining, false memories \& personal meanings, „Consciousness and Cognition”, t. 33 (2015), s. 574-581. 
zorganizowana jest hierarchicznie w taki sposób, że wiedza o zdarzeniach specyficznych (np. oświadczyny) jest częścią wiedzy o zdarzeniach ogólnych (np. piątkowe wieczory), a ta z kolei - wiedzy o okresach życia (np. okres studiów), na każdym zaś z tych poziomów wiedza jest zorganizowana tematycznie ${ }^{26}$. Osoba przypominając sobie zdarzenia, sięga do danego poziomu, z którego może poruszać się w dół lub w górę hierarchii.

Rekomendujemy zatem przygotowanie kwestionariusza, który:

- sięga do pamięci doświadczeń respondenta związanych z okresami jego życia (indywidualnymi, ale określonymi czynnikami zewnętrznymi, czyli występującymi w chronologii stosunkowo łatwo sprawdzalnej w innych źródłach, np. szkoła, małżeństwo itp.). Wywiad nie dotyczy całego życiorysu, więc znając przybliżony wiek respondenta i posiadając ogólną wiedzę o jego biografii, a także będąc wcześniej wyposażeni w adekwatną wiedzę historyczną, przygotowujemy kwestionariusz, który pozwoli na zanurzenie się respondenta w czas np. jego edukacji w szkole średniej;

- w odniesieniu do okresów życia zawiera pytania związane z konkretnymi: miejscami/przestrzenią, przedmiotami, ludźmi i ideami (lista ta nie jest zamknięta $\mathrm{i}$ jedynie wskazuje kierunek pracy badacza nad kwestionariuszem).

Optymalny byłby tu kwestionariusz w formie graficznej mapy myśli, gdyż pozwala on na powiązanie pytań badawczych z tymi polami (przestrzenią, przedmiotami, ludźmi i ideami) wraz z przełożeniem i rozwinięciem w konkretne pytania do użycia w rozmowie. Ze względu na swe (potencjalnie duże) fizyczne rozmiary taka graficzna mapa może być jednak nieporęczna podczas wywiadu, dlatego można ograniczyć się do listy pogrupowanych pytań.

Posiadanie przy sobie podczas wywiadu pełnego i szczegółowo spisanego kwestionariusza (z dosłownie sformułowanymi pytaniami) zdecydowanie rekomendujemy z dwóch głównych powodów:

- wywiad prowadzony według proponowanego modelu, tak jak każdy wywiad ustrukturyzowany wymaga dużej czujności i kontroli ze strony badacza, zatem należy minimalizować ryzyko błędów i przeoczeń, które mogą się pojawić w trakcie spotkania;

- rygor naukowy podczas wywiadu powinien umożliwiać zdobycie materiałów do porównawczej analizy historycznej, a zadanie tych samych (tak samo sformułowanych) pytań różnym rozmówcom zwiększa na to szanse.

Do umiejętności komunikacyjnych badacza, które w proponowanej metodzie wspierają odtwarzanie wspomnień, zaliczamy, obok wspomnianej zdolności pytania i dopytywania, bierne i aktywne słuchanie ${ }^{27}$. Bierne słuchanie

27 Por.: Swobodne techniki diagnostyczne. Wywiad i obserwacja, red. T. Szustrowa, Warszawa 1991. 
to pozwalanie respondentowi na mówienie, ale też rozumienie i tolerowanie ciszy, a także niewerbalne okazywanie zainteresowania. Nie jest to jednak równoznaczne z rezygnacją z kontroli nad wywiadem i dlatego tak ważne jest korzystanie podczas wywiadu ze spisanego kwestionariusza pytań, które powinny zostać zadane w przewidzianym w kontrakcie czasie. Długość pojedynczej rozmowy nie powinna zaś, jak wspomniano wyżej, przekraczać 90 minut, co potwierdzają zarówno dotychczasowe doświadczenia własne podczas testowania niniejszej metody, jak i ogólna praktyka psychologów, diagnostów i terapeutów. Od uczestników badania wymagane jest tu duże skupienie uwagi i wysiłek umysłowy, który po rekomendowanym czasie 90 minut powoduje nadmierne zmęczenie obu stron i negatywnie wpływa na jakość uzyskanego materiału.

Do technik aktywnego słuchania, które są szczególnie przydatne w wywiadzie zaliczamy: parafrazowanie, klaryfikowanie i odzwierciedlenie, a także podsumowywanie poszczególnych sesji wywiadu. Parafraza, czyli wypowiedź treściowo tożsama z wypowiedzią respondenta, ale sformułowana innymi słowami, daje rozmówcy dowód, że jesteśmy uważnymi słuchaczami, i pozwala zweryfikować, czy badacz poprawnie zrozumiał usłyszaną wypowiedź (np.: „Rozumiem, że wtedy właśnie koledzy wywiesili ten transparent na płocie, ale pan(i) nie brał(a) w tym udziału"). Klaryfikacja, dzięki koncentracji na głównym wątku lub ważnym dla danych badań fragmencie wypowiedzi, pozwala wyjaśnić nieścisłości i uporządkować dane, szczególnie gdy relacja jest chaotyczna (np.: „Nie jestem pewna, co było pierwsze: czy najpierw usłyszał(a) pan(i) strzały, czy najpierw nadjechał samochód”, „Czy chodzi o to, że...?”). Odzwierciedlenie natomiast to technika pomagająca w momencie doświadczenia przez respondenta trudnych uczuć, który dla badacza jest zazwyczaj kłopotliwy. Celem odzwierciedlenia jest skoncentrowanie się na emocjach zawartych w wypowiedzi lub towarzyszących mówieniu i zwerbalizowanie tego, co się słyszy. W ten sposób pokazujemy respondentowi, że tej sfery nie ignorujemy (np.: „Słyszę, że jest pan(i) poruszony(a) wspomnieniem tego wydarzenia”), a dzięki takiemu „przejrzeniu się w lustrze” respondent nie zagłębia się w przeżywanie uczuć, nad czym mógłby w obecności badacza stracić kontrolę, a po czasie tego żałować. Każdą z tych trzech technik warto przećwiczyć przed wywiadami, np. w zespole badawczym, ale też indywidualnie (np. czytając dowolny wywiad prasowy, przygotować doń zestaw naszych wypowiedzi parafrazujących, klaryfikujących i odzwierciedlających).

Badania naukowe pokazują, że wraz z upływem czasu zwiększa się prawdopodobieństwo, że zdarzenie będzie przypomniane z mniejszą szczegółowością lub błędnie. Wynika to z jednej strony z procesu zacierania się śladu pamięciowego, a z drugiej - ze wzrastającego prawdopodobieństwa kontaktu z innymi, nieepizodycznymi informacjami na temat zdarzenia (np. od innych świadków), które 
mogą wpłynąć na jego pamięćc $c^{28}$. Takie dodatkowe informacje już po kilku dniach łączą się z pamięcią osobiście ważnego i intensywnego zdarzenia ${ }^{29}$. Tomasz Maruszewski zwraca uwagę, że do indywidualnych śladów pamięciowych dopisywane są informacje pochodzące $\mathrm{z}$ wielu różnych źródeł, także z medió $w^{30}$. Badania wskazują również na to, że ludzie wraz z upływem czasu tracą informacje dotyczące źródła informacji (efekt monitorowania źródła ${ }^{31}$ ) i w konsekwencji, podczas odtwarzania mogą już nie rozróżniać, czy znają fakt od osoby, czy z przekazu (czy np. był to fakenews, zasłyszany żart czy może relacja naocznego świadka). Świadome przypomnienie sobie źródła przekazu może pozwolić w pewnym zakresie kontrolować ten naturalny proces. Warto pamiętać, że efekt ten dotyczy szczególnie osób starszych ${ }^{32}$. Zatem pamięć można traktować mniej indywidualnie, bardziej podkreślając współkonstruowanie i nakładanie się różnych informacji na siebie. Narzędziem kontroli tego zjawiska przez badacza jest bezpośrednie pytanie o źródło danej informacji (czy osoba była naocznym świadkiem/uczestnikiem zdarzenia, czy może przeczytała o tym lub usłyszała później i włączyła w swój obraz tego zdarzenia?) ${ }^{33}$.

Badania dowodzą również, że wielokrotne powtarzanie informacji zapisanych w pamięci semantycznej sprzyja lepszemu ich zapamiętywaniu. Z pamięcią epizodyczną jest odwrotnie - im więcej razy opowiadane zdarzenie (np. przez świadków i uczestników ważnych historycznych wydarzeń), tym większe zniekształcenia pamięci mogą się pojawićs ${ }^{34}$. Wzmacnia to potrzebę dobrego przygotowania badacza do wywiadu, tzn. oprócz wiedzy historycznej na temat zdarzeń czy okresu, którego dotyczy wywiad, należy zdobyć informacje o rozmówcy, a w szczególności dowiedzieć się, czy nie spisał on już wcześniej swoich wspomnień (może nawet opublikował?) lub czy nie udzielał wywiadów. Warto więc wiedzieć zawczasu, z jak mocno przepytanym respondentem mamy do czynienia.

Dla odtwarzania pojedynczego zdarzenia znaczenie ma również wielokrotne uczestnictwo w podobnych zdarzeniach. Rzadko pamięta się szczegóły zdarzenia, które jest częścią wielokrotnych doświadczeń, ponieważ byłoby to bardzo obcią-

28 L. Hope, F. Gabbert, R.P. Fisher, From laboratory to the street: Capturing witness memory using the Self-Administered Interview, „Legal and Criminological Psychology”, t. 16 (2011), nr 2, S. 211-226.

29 Zob. A. Niedźwieńska, op. cit.

30 T. Maruszewski, op. cit.

31 M.K. Johnson, S. Hashtroudi, D.S. Lindsay, Source monitoring, „Psychological Bulletin”, t. 114 (1993), s. 3-28, http://dx.doi.org/10.1037/0033- 2909.114.1.3 (dostęp: 15 XII 2020 r.).

32 J. Dywan, L. Jacoby, Effects of aging on source monitoring: Differences in susceptibility to false fame, „Psychology and Aging”, t. 5(3) (1990), s. 379.

33 Zob.: A. Niedźwieńska, op. cit.

34 Np.: M. Linton, Ways of searching and the contents of memory. Autobiographical memory, [w:] Autobiographical memory, red. D.C. Rubin, Cambridge 1986, s. 50-67. 
żające poznawczo zadanie ${ }^{35}$. Jeśli interesuje nas określony typ zdarzeń, w których rozmówca wielokrotnie uczestniczył (np. wiele razy wypływał w morze, a my pytamy o przebieg początkowego etapu konkretnego rejsu), to możemy oczekiwać, że opowiada coś na kształt „kompilacji” faktograficznej i osobistych ustosunkowań (jest to tzw. błąd nadużycia schematu) ${ }^{36}$.

Uogólnienia poszczególnych zdarzeń w określony typ zdarzeń często spotykamy u osób starszych, które mogą mieć trudności z dostępem do konkretnych danych epizodycznych, a deficyt ten może być automatycznie kompensowany przez korzystanie z pamięci semantycznej ${ }^{37}$. Badacz może wspomagać przypominanie zdarzeń semantyczną wiedzą autobiograficzną respondenta. Na przykład, kiedy respondent opowiada o drodze do szkoły, można dopytać, ile miał wtedy lat i co świadczy o tym, że to było właśnie wtedy. Czasem pomaga podsunięcie respondentowi rozróżnienia „wiem” od „pamiętam”" ${ }^{38}$, wyrażające akceptację obu odrębnych źródeł informacji wiedzy. Tyczy się to np. sytuacji, w której respondent, wspominając wydarzenie ze swojego dzieciństwa, może posiłkować się pamięcią semantyczną do opisu fragmentów rzeczywistości, których - z racji jego ówczesnego wieku i roli społecznej - z dużym prawdopodobieństwem nie mógł doświadczyć. Przy rozwiniętej współpracy nad zadaniem, jakim jest wywiad, respondent uczy się w nim uczestniczyć bardziej produktywnie, ponieważ rozumie nasze cele jako badaczy.

$\mathrm{Z}$ badań wiadomo, że zadawanie nakierowujących pytań, wprowadzanie dodatkowych informacji oraz wywieranie jakiegokolwiek nacisku na rozmówcę (np. czasowego, moralnego) może spowodować niedokładne podanie przez niego danych ${ }^{39}$. W proponowanej metodzie wywiadu jesteśmy więc, jako badacze, zobligowani do uświadomienia sobie własnych motywacji, a potem wyeliminowania ukrytego i jawnego nacisku. Uznawanie odpowiedzi „nie wiem” i „nie pamiętam” za naturalne, jest nie tylko dowodem naszej wiedzy, że rozmówca może nie pamiętać, bo właściwością pamięci jest zapominanie, ale również pozwala na uniknięcie niepotrzebnego napięcia lub poczucia nieadekwatności i zaniżenia samooceny u respondenta. Dobra atmosfera wywiadu, wyrażająca wzajemny szacunek, równość T. Maruszewski, op. cit.

38

Por.: T. Maruszewski, op. cit.

Zob.: A. Niedźwieńska, op. cit.

Zob.: A. Niedźwieńska, op. cit.

Por.: B. Levine, E. Svoboda, J.F. Hay, G. Winocur, Aging and autobiographical memory: dissociating episodic from semantic retrieval, „Psychology and Aging”, t. 17 (2002), nr 4, s. 677;

E.F. Loftus, Planting misinformation in the human mind: A 30 -year investigation of the malleability of memory, „Learning \& Memory”, t. 12 (2005), nr 4, s. 361-366, na podst.: J. Shaw, S. Porter, Constructing rich false memories of committing crime, „Psychological Science”, 26 (2015), nr 3, s. 291-301. 
i poczucie zrozumienia, może zachęcić do wysiłku przypomnienia sobie tego, co rozmówca może rzeczywiście pamiętać, i podzielenia się tym z badaczem w otwarty sposób.

W literaturze na temat pamięci biograficznej wiele uwagi poświęcono zjawisku tzw. fałszywych wspomnień i rozważaniom, czy można indukować komuś wspomnienia, których nie miał (np. poprzez ich sugerowanie $)^{40}$. Obecnie większość badaczy sądzi, że „fałszywe wspomnienia” pojawiają się w specyficznych okolicznościach: dotyczą odległej przeszłości i rozmówców z osobowością skłonną do tzw. dysocjacji, sprzyja temu sposób prezentowania fotografii, sugerujący, że rozmówca powinien znać dane zdjęcie ${ }^{41}$. $\mathrm{Z}$ tego ostatniego względu, chcąc posłużyć się fotografią lub innymi dokumentami podczas wywiadu, warto przemyśleć swój komentarz tak, aby niczego takiego nie sugerować.

Niezamierzony wpływ na respondenta i jego opowieść może mieć również temperament badacza, w szczególności jeśli ekstrawertyk będzie prowadził wywiad z osobą wycofaną, np. introwertywną ${ }^{42}$. Powstały w takiej relacji nacisk społeczny może być trudny do świadomego uchwycenia przez obie strony i do jawnej na niego reakcji, zwłaszcza że każda ze stron będzie zapewne chciała wywiązać się ze swojego zadania jak najlepiej. Jedynym sposobem, by takiej sytuacji zapobiec, wydaje się podjęcie przez badacza próby obserwacji siebie i respondenta pod kątem ewentualnego nacisku społecznego i wysiłek, by osłabić jego wpływ na pozyskiwane dane. W przypadku prowadzenia wywiadów z seniorami warto pamiętać, że według badań są oni bardziej podatni na pytania sugerujące odpowiedź (lub jej kierunek) niż młodzi dorośli $i^{43}$. Trafne wspomnienia trudniej też uzyskać od osób, które uważają, że ich pamięć nie jest dobra - ci rozmówcy są szczególnie wyczuleni na informacje zwrotne i mogą łatwo poddać się sugestii osoby prowadzącej wywiad ${ }^{44}$.

Podsumowując, w fazie komunikacyjnej wywiadu rolą dobrze przygotowanego badacza jest:

a) przyjmowanie odpowiedzi „nie wiem" $i$,nie pamiętam”,

40 Np.: J. Shaw, S. Porter, op. cit.

41 A. Niedźwieńska, op. cit., na podst.: D.S. Lindsay, L. Hagen, J.D. Read, K.A. Wade, M. Garry, True photographs and false memories, „Psychological Science”, t. 15 (2004), nr 3, s. 149-154.

42 Na podst.: S. Porter, A. Birt, D.R. Lehman, Negotiating False Memories: Interviewer and Rememberer Characteristics Relate to Memory Distortion, „Psychological Science”, t. 11 (2000), nr 6, s. 507-510.

43 Zob.: K. Mueller-Johnson, S.J. Ceci, Memory and suggestibility in older adults: Live event participation and repeated interview, „Applied Cognitive Psychology”, t. 18 (2004), nr 8, s. 1109-1127.

44 H. McMurtrie, J.S. Baxter, M.C. Obonsawin, S.C. Hunter, The relationship between memory beliefs, compliance and response change within a simulated forensic interview, „Personality and Individual Differences", t. 52 (2012), nr 5, s. 591-595. 
b) rozróżnianie „wiem” od „pamiętam” respondenta,

c) dopytywanie wprost,

d) eksplorowanie z respondentem sceny „siebie w tamtym czasie”, w której zanurza się mentalnie w ówczesnych myślach, uczuciach, przestrzeni, czasie, sekwencjach epizodu,

e) ograniczanie potencjalnych sugestii, mogących kształtować fałszywe wspomnienia,

f) uświadomienie wpływu własnego temperamentu na przebieg wywiadu,

g) konsekwentne prezentowanie etycznej postawy w relacji z respondentem.

Faza III. Zamknięcie sytuacji badawczej.

Ostatnia faza wywiadu to podsumowanie rozmowy i sprawdzenie, czy budzące wątpliwości informacje zostały zrozumiane zgodnie z intencją respondenta. Po zamknięciu części informacyjnej możliwy jest powrót do warunków kontraktu i przedyskutowanie ewentualnych zmian, jakie respondent chciałby wprowadzić w zasadach np. udostępniania. Ponieważ doświadczenie pracy historyków pokazuje, że respondent już po wyłączeniu urządzenia nagrywającego często chce coś dodać lub skorygować podane informacje, rekomendujemy odpowiednio zapisanie notatki (jeśli korekta polega na dodaniu niewielkiego szczegółu) lub umówienie się na kolejną sesję (jeśli chodzi o dłuższe wyjaśnienia). Jeżeli zaś rozmówca naciska na kolejne wizyty, mimo wcześniejszego uzgodnienia na początku spotkania, że jest to sesja ostatnia, zalecamy stanowcze zamknięcie relacji. Ostatni etap wywiadu powinno zakończyć ustalenie szczegółów przekazania przez badacza ewentualnej publikacji.

Przedstawione tu procedury wywiadu mają na celu stworzenie takich warunków komunikacji podczas wywiadu, w których - przy jednoczesnym upodmiotowieniu respondenta - powstaną materiały informacyjne porównywalne i weryfikowalne na drodze podstawowej analizy historycznej. Elementem wyróżniającym proponowaną metodę spośród innych wywiadów ustrukturyzowanych, w tym wywiadu faktograficznego, jest nacisk na wywołanie efektu „zanurzenia” (imersji) świadka w przeszłym doświadczeniu. Przygotowanie się badacza do tego rodzaju wywiadu wymaga rzecz jasna uprzedniej realizacji wcześniejszych, typowych dla każdego projektu naukowego etapów, takich jak sformułowanie problemu badawczego i bardziej szczegółowych pytań badawczych, opracowanie merytoryczne tematu, w tym poznanie dostępnych w innych źródłach informacji biograficznych na temat osoby, z którą będziemy rozmawiać (o ile to oczywiście wykonalne). Częścią przygotowania do samego wywiadu jest też - najbardziej 
twórczy, trudny i często do końca nie zamknięty - etap tworzenia kwestionariusza oraz trening umiejętności komunikacyjnych. Solidne przygotowanie do wywiadu i przeprowadzanie go w proponowanym modelu ułatwi analizę tak wywołanego źródła historycznego. Z kolei większa liczba wywiadów przeprowadzonych w jednej procedurze daje korpus źródeł, które są porównywalne. Sam wywiad, jako spotkanie ze świadkiem historii, powinien być traktowany jako niepowtarzalna szansa poznawcza, której historyk nie może zmarnować. Mimo że w niniejszym tekście skupiliśmy się na poznawczych celach metody, chcemy podkreślić, że etyczne kwestie są w niej kwestią pierwszoplanową. Dlatego w proponowane przez nas procedury wpisane jest założenie o rezygnacji z badań, jeśli tylko ze strony świadka pojawi się pragnienie odmowy lub przerwania wywiadu. 


\section{Załącznik 1. Kontraktowanie wywiadu.}

Instrukcja zawiera pytania i sformułowania, które powinny paść w przedstawionej kolejności podczas kontraktowania wywiadu. Tekst powinien być przed spotkaniem przećwiczony przez badacza (przeczytany kilka razy głośno). W trakcie kontraktowania może być w całości odczytany, ale ważne jest, by odbywało się to wolno i w kontakcie wzrokowym z respondentem. Respondent powinien mieć pewność, że badacz czeka z uwagą na jego odpowiedzi, jest otwarty na ewentualne pytania i gotowy do udzielenia wyjaśnień.

Kontraktowanie wywiadu odbywa się pomiędzy dorosłymi, wolnymi ludźmi, będącymi w pełni władz umysłowych. Należy pamiętać, że respondent ma prawo wycofać się z badania w dowolnym momencie.

\section{WSTĘP - PRZED WŁĄCZENIEM DYKTAFONU:}

1. Bardzo dziękuję, że zgodził/a się Pan/i na tę rozmowę.

2. Czy nie zmienił/a Pan/i zdania?

[CZAS NA ODPOWIEDŹ]

3. Bardzo się cieszę ${ }^{45}$.

4. Chciał(a)bym przed rozpoczęciem rozmowy poświęcić kilka chwil na wyjaśnienie, dlaczego poprosiłem/am o ten wywiad i przedstawić, jak będzie on mniej więcej wyglądał. I przede wszystkim - ustalić zasady jego wykorzystania.

5. Jeśli będzie Pan/i miał/a jakiekolwiek pytania albo wątpliwości, proszę o sygnał, dobrze?

[CZAS NA ODPOWIEDŹ]

6. Chciał(a)bym też już teraz włączyć dyktafon. Tak żeby nagrało się też moje wyjaśnienie i ustalone wspólnie zasady wykorzystania.

7. Czy nie ma Pan/i nic przeciwko włączeniu tego sprzętu? [POKAZAĆ DYKTAFON]

[CZAS NA ODPOWIEDŹ]

[WŁĄCZENIE DYKTAFONU ${ }^{46}$ ]

45 Jeśli rozmówca zdecydowanie odmawia, dziękujemy i kończymy spotkanie. Jeśli natomiast wyraża dalsze wątpliwości, przechodzimy do punktu 4 celem dalszych wyjaśnień.

46 Jeśli rozmówca wyraża dalsze wątpliwości co do warunków rozmowy, należy je rozwiać, aż do uzyskania zgody na włączenie dyktafonu. 


\section{KONTRAKT [po włączeniu dyktafonu]}

\section{A. WYJAŚNIENIE}

1. Jeszcze raz bardzo Panu/i dziękuję, że zgodził(a) się Pan(i) na tę rozmowę. [PAUZA]

2. Poprosiłem o tę rozmowę, bo jak wiem... ${ }^{47}$.

3. Jestem historykiem, a w badaniach, które obecnie prowadzę, zajmuję się... ${ }^{48}$.

4. Szczególnie interesuje mnie właśnie... ${ }^{49}$.

[PAUZA]

5. Wywiad może czasami przypominać luźną rozmowę, nie jest prowadzony według ścisłego kwestionariusza.

[PAUZA]

6. Chociaż jednocześnie będę chciał(a) zadać szereg pytań, które są dla mnie ważne z punktu widzenia prowadzonych badań. Nie znaczy to, że wywiad będzie przesłuchaniem. Ale jeśli sposób zadawania pytań stanie się dla Pana/Pani niekomfortowy, proszę mi to zasygnalizować, dobrze?

[CZAS NA ODPOWIEDŹ]

7. Zależy mi przede wszystkim na tym, by spróbował(a) się Pan(i) wczuć w siebie w tamtym czasie; jestem też otwarty/a na Pana/i opinie, spostrzeżenia. Co więcej - bardzo prawdopodobne, że pod ich wpływem zmianie ulegną przygotowane przeze mnie pytania i przyjęte założenia.

8. Gdyby nasunęło się Panu/i w trakcie coś ważnego, a ja nie zadam o to pytania, proszę dać mi znać, dobrze?

[CZAS NA ODPOWIEDŹ]

9. Rozmowa będzie trwała około godziny, a na pewno nie dłużej niż 1,5 godziny.

10. Czy ma Pan/i tyle czasu?

[CZAS NA ODPOWIEDŹ]

11. Może się zdarzyć, że zadam pytania, na które nie będzie chciał(a) Pan(i) odpowiadać. Proszę skorzystać wtedy z prawa odmowy odpowiedzi. Możemy też wtedy po prostu zmienić temat.

12. Ma Pan/i także prawo do zakończenia rozmowy w każdej chwili.

13. Czy wszystko do tej pory jest jasne?

[CZAS NA ODPOWIEDŹ]

47 Np.: Poprosiłem o tę rozmowę, bo, jak wiem, zaczął/ęła Pan/i studia na przełomie lat 80. i 90 .

48 Np.: Jestem historykiem, a w badaniach, które obecnie prowadzę, zajmuję się pokoleniem ludzi, którzy w dorosłość wchodzili pod koniec lat 80. i na początku kolejnej dekady.

49 Np.: Szczególnie interesuje mnie właśnie sam moment wchodzenia w dorosłość, który wiążemy z okresem studiów. 


\section{B. CZĘŚĆ FORMALNA [CZYTAĆ WOLNO, UNIKAĆ WYLICZANIA]:}

Ponieważ nasza nagrana rozmowa służy badaniom naukowym, chciał(a)bym mieć pewność, że będziemy mogli pracować na nagranym materiale. W związku z tym chciał(a)bym się upewnić:

1. Czy chce Pan/i wziąć udział w tym badaniu?

[CZAS NA ODPOWIEDŹ]

2. Czy zgadza się Pan/i na nagranie rozmowy?

[CZAS NA ODPOWIEDŹ]

3. Czy inni badacze biorący udział w projekcie będą mogli zacytować Pana/i wypowiedzi?

[CZAS NA ODPOWIEDŹ]

4. Pana/Pani wypowiedzi mogą pozostać anonimowe. Do tej kwestii możemy jeszcze powrócić po zakończeniu nagrania.

[PAUZA]

5. Chciał(a)bym tylko zastrzec, że nie będę mógł/mogła ukryć regionu i miasta, z którego Pan/i pochodzi oraz mieszka czy mieszkał(a), a także Pana/i wieku i płci. Te informacje są ważne dla badań. Możemy natomiast nie publikować żadnych imion lub nazwisk, które nie są imionami osób publicznych.

6. Czy zgadza się Pan/i na takie rozwiązanie?

[CZAS NA ODPOWIEDŹ]

7. [Jeśli dysponujemy na ten temat wiedzą:] Nagrana relacja zostanie/może zostać użyta/zamieszczona/opublikowana w...

8. Czy wyraża Pan/i na to zgodę?

[CZAS NA ODPOWIEDŹ]

9. I jeszcze kwestia dostępu oraz przechowywania nagrań i materiałów.

10. Będą one przechowywane trakcie trwania projektu w... ${ }^{50}$ [, a później, po zakończeniu projektu... ${ }^{51}$.

[PAUZA]

11. Dostęp do nich będą mieć... ${ }^{52}$.

12. Ewentualna zmiana sposobu udostępniania odbędzie się wyłącznie za Pana/i wiedzą i zgodą.

13. Czy akceptuje Pan/i takie rozwiązanie?

[CZAS NA ODPOWIEDŹ]

50 Np.: ...zamkniętej szafie w pomieszczeniu, do którego dostęp mają tylko członkowie zespołu badawczego.

51 Jeśli to możliwe, warto dookreślić, w jakim archiwum.

52 Np.: ...członkowie zespołu badawczego. 
14. Zanim przejdziemy do samej rozmowy, chciał(a)bym zapytać, czy nasunęły się Panu/i jakieś uwagi albo wątpliwości? Czy wszystko jak dotąd jest jasne? Czy wszystko jest w porządku? ? $^{53}$

[CZAS NA ODPOWIEDŹ - NIE SPIESZYĆ SIĘ, NAWIĄZYWAĆ KONTAKT WZROKOWY, NIE PATRZEĆ W KARTKĘ]

15. Teraz przejdę już do zadawania pytań. Proszę pamiętać, że może Pan(i) w każdej chwili wywiad przerwać, zakończyć albo poprosić o wyłączenie dyktafonu na chwilę. Może Pan(i) też zastrzec już w trakcie rozmowy, żeby usunąć dany fragment.

[POCZEKAĆ NA REAKCJĘ, NAWIĄZYWAĆ KONTAKT WZROKOWY]

53 Jest to pytanie o samopoczucie rozmówcy, a nie o zrozumienie warunków kontraktu. 


\section{Bibliografia}

Brewin C.R., Andrews B., Mickes L., Regaining Consensus on the Reliability of Memory, „Current Directions in Psychological Science", t. 29 (2020), nr 2, s. 121-125.

Conway M.A., Episodic memories, „Neuropsychologia”, t. 47 (2009), nr 11, s. 2305-2313.

Conway M.A., Loveday C., Remembering, imagining, false memories \& personal meanings, „Consciousness and Cognition", t. 33 (2015), s. 574-581.

Dywan J., Jacoby L., Effects of aging on source monitoring: Differences in susceptibility to false fame, „Psychology and Aging”, t. 5(3) (1990), s. 379-387.

Elder G.H., Children of the Great Depression: Social Change in Life Experience, Boulder-Oxford 1999.

Filipkowski P., Historia mówiona jako historia faktyczna albo jak „odantropologizować” opowieści o przeszłości?, „Rocznik Antropologii Historii”, t. 5 (2015), s. 91-108.

Filipkowski P., Kurkowska-Budzan M., Rakowski T., Stasiak M., Reanimacje i rewitalizacje - relacje ustne jako czynnik innowacji w badaniach historycznych. Głosy w dyskusji, „Rocznik Antropologii Historii", t. 12 (2019), s. 311-320.

Gilboa A., Rosenbaum S., Mendelsohn A., Autobiographical memory: from experiences to brain representations, „Neuropsychologia”, t. 110 (2018), s. 1-6.

Goldsmith M., Koriat A., The strategic regulation of memory accuracy and informativeness, „Psychology of Learning and Motivation", t. 48 (2007), s. 1-60.

Hope L., Gabbert F., Fisher R.P., From laboratory to the street: Capturing witness memory using the Self-Administered Interview, „Legal and Criminological Psychology”, t. 16 (2011), nr 2, s. 211-226.

Jagodzińska M., Psychologia pamięci. Badania, teorie, zastosowania, Gliwice 2008.

Johnson M.K., Hashtroudi S., Lindsay D.S., Source monitoring, „Psychological Bulletin”, t. 114 (1993), S. 3-28.

Klein S.B., Self, memory, and the self-reference effect: an examination of conceptual and methodological issues, „Personality and Social Psychology Review”, t. 16 (2012), s. 283-300.

Kvale S., Prowadzenie wywiadów, Warszawa 2010.

Levine B., Svoboda E., Hay J.F., Winocur G., Aging and autobiographical memory: dissociating episodic from semantic retrieval, „Psychology and Aging”, t. 17 (2002), nr 4, s. 2189-2208.

Lindsay D.S., Hagen L., Read J.D., Wade K.A., Garry M., True photographs and false memories, „Psychological Science", t. 15 (2004), nr 3, s. 149-154.

Linton M., Ways of searching and the contents of memory. Autobiographical memory, [w:] Autobiographical memory, red. D.C. Rubin, Cambridge 1986, s. 50-67.

Loftus E.F., Planting misinformation in the human mind: A 30-year investigation of the malleability of memory, „Learning \& Memory”, t. 12 (2005), nr 4, s. 361-366.

Maruszewski T., Pamięć autobiograficzna - nowe dane, „Neuropsychiatria i Neuropsychologia”, t. 5 (2010), nr 3-4, s. 122-129.

McMurtrie H., Baxter J.S., Obonsawin M.C., Hunter S.C., The relationship between memory beliefs, compliance and response change within a simulated forensic interview, „Personality and individual differences", t. 52 (2012), nr 5, s. 591-595. 
Morgan D.L., Guevara H., Rapport, [w:] The SAGE Encyclopedia of Qualitative Research Methods, red. L.M. Given, Sage 2008, s. 728-729.

Mueller-Johnson K., Ceci S.J., Memory and suggestibility in older adults: Live event participation and repeated interview, „Applied Cognitive Psychology”, t. 18 (2004), nr 8, s. 1109-1127.

Niedźwieńska A., Poznawcze mechanizmy zniekształceń w pamięci zdarzeń, Kraków 2004.

Porter S., Birt A., Lehman D.R., Negotiating False Memories: Interviewer and Rememberer Characteristics Relate to Memory Distortion, „Psychological Science”, t. 11 (2000), nr 6, s. 507-510.

Rakowski T., Historia mówiona i źródła etnograficzne jako „wiedza pewna”. Przypadek potransformacyjnej historii Torgutów w zachodniej Mongolii oraz historii wsi Broniów w centralnej Polsce, „Rocznik Antropologii Historii”, t. 5 (2015), s. 59-90.

Shaw J., Porter S., Constructing rich false memories of committing crime, „Psychological Science”, 26 (2015), nr 3, s. 291-301.

Stasiak M., „Czy więc byliśmy i jesteśmy naiwni...?” Jeszcze jeden głos w debacie nad wykorzystaniem relacji ustnych $w$ badaniach najnowszej historii Polski, „Wrocławski Rocznik Historii Mówionej", t. 8 (2018), s. 29-61.

Swobodne techniki diagnostyczne. Wywiad i obserwacja, red. T. Szustrowa, Warszawa 1991.

Tulving E., Episodic memory: from mind to brain, „Annual Review of Psychology”, t. 53 (2002), s. 1-25.

Wojciechowski B.W., Analiza i ocena zeznań świadków, Sopot 2015. 


\section{Summary}

The text presents the procedures and techniques involved in a research method aimed at "evoking a historical source", which is understood as a researcher's prepared and academically rigorously implemented participation in the creation by a witness to history of such recollective material that might be a carrier of information and that might be subject to rudimentary historical analysis, i.e. comparison and/or verification against information from other sources. The element that distinguishes the proposed method from the range of available structured interviews is its emphasis on evoking the effect of the "immersion" of the witness in the past experience. In turn, the text presents the following: basic academic findings in the field of psychology which form the epistemological and methodological foundation of the proposed procedures; defined assumptions and subsequent stages of the research procedure; the mechanics of transforming research questions into a questionnaire (in tabular form); and recommendations regarding communication during the interview, which should create conditions conducive to the professionalization of the relationship between the witness and the researcher, leading to a simultaneous beneficial impact upon the recollection of memories. 